\title{
LETTER-T0-EDITOR
}

\section{Bridging the Gap between Knowledge and Practice in using Personal Protective Measures for Infection Control}

Sir,

I would like to congratulate Rachna Kaul and her co-workers ${ }^{1}$ for highlighting a very important issue regarding usage of protective eye wear among dental practitioners of Bengaluru city. It has emphasized on work related eye/ vision hazards and also found that $55.3 \%$ of dental practioner's used protective eye wear in Bengaluru city. To add to the present data, in one of our survey on infection control practices among endodontic postgraduate students of Bengaluru city, it was observed that hardly $22.8 \%$ (21/92) used protective eyewear compared to other personal protective measures even though they were aware showing lacunae in the knowledge and practice. ${ }^{2}$

Many studies ${ }^{3-5}$ showed the negligence of wearing protective eye wear among dentists in spite of knowing that it is one of the personal protective equipment recommended. Interestingly a study has shown that not only dental practitioners but people in medical field also give less importance for the use of eye wear. ${ }^{6}$ All these indicate that the students learnt infection control measures from faculty lessons showing increased knowledge, but when it has to be practiced, the number was very less. As Kaul et $\mathrm{al}^{1}$ concludes to increase the awareness among dentists, along with it reviewing the guidelines should be emphasized. One should abide themselves to the universal guidelines like 'Standard infection control and precautions', 'American Dental Association Recommendations' and guidelines set by center for disease control and prevention. ${ }^{2,8}$ In addition, reinforcement of knowledge by continuing dental education programs and short training courses about cross infection and infection control procedures are recommended for dental students, dentists, and dental assistants to upgrade themselves. But, as the studies have stated the gap between knowledge, attitude and practice do exist, to address these shortfalls and to improve the adherence to procedures, constant motivation becomes the key factor.

\section{REFERENCES}

1. Rachna Kaul, Shilpa PS, Sanjay CJ. Usage of protective eye wear among dental practitioners of Bengaluru city: a survey with review of literature. World J Dent 2014;5(1):17-20.

2. Arun A, Venugopal P, Jyothi KN, Mythri H, Harikrishna V. Knowledge and attitude of endodontic postgraduate students toward sterilization of endodontic files: a cross-sectional study. Saudi Endodont J 2014;4(1):18-22.

3. Akbulut N, Öztaş B, Kurşun S, Çölok G. Knowledge, attitude and behavior regarding hepatitis B and infection control in dental clinical students. Clin Dent Res 2011;35(2):21-27.

4. Emir Y, Duygu S, Sevgi C, Y Sinasi S, Seda C. A survey of cross-infection control procedures: knowledge and attitudes of Turkish dentists. J Appl Oral Sci 2009;17(6):565-569.

5. Askarian M, Assadian O. Infection control practices among dental professionals in Shiraz dentistry school, Iran. Arch Iran Med 2009;12(1):48-51.

6. Sessa A, Gabriella DG, Luciana A, Italo FA. The collaborative working group. An investigation of nurse's knowledge, attitudes and practices regarding disinfection procedures in Italy. BMC Inf Dis 2011May;11:148.

7. Hoy J.Standard precautions and infection control—ASHM. Available at: www.ashm.org.au/images/....../hiv_viral_hep_chapter_13. pdf. Cited on 21/9/13.

8. CDC Guidelines for Infection Control in Dental Health Care Settings-2003.

Mythri Halappa
Senior Lecturer
Department of Public Health Dentistry
Sri Siddhartha Dental College
Tumkur, Karnataka, India
Arun Aslam
Reader
Department of Conservative Dentistry and Endodontics
RV Dental College, Bengaluru, Karnataka, India




\title{
World Journal of Dentistry
}

\author{
Copyright Ownership and Legal Rights Statement
}

\section{CONDITIONS FOR SUBMISSION}

You warrant that the work/contribution is your original research material and has not been published before and should not be under consideration of publication elsewhere except for previous publication in form of an abstract or as part of published literature (review or thesis) as may be included with the written permission of the copyright owners. You further warrant that the work/contribution (i) is not subject to any prior claim, encumbrance or agreement, (ii) will include appropriate warnings of harmful instructions, formulas and procedures, and (iii) will not contain any material that violates any copyright, personal proprietary or other right. This exclusive grant of rights under this Agreement means that you may not delegate, assign, sub-contract or license the work/contribution in whole or in part to third parties without the prior written consent of the Publisher.

If your work/contribution contains extracts or material from other copyright works, you will obtain at your own expense before a paper can be considered for publication along with written permission, which shall be forwarded to the Publisher on delivery of the work/contribution from each copyright holder to use and reprint such material in all versions, forms and media now or hereafter known, including all existing and future copyright and any renewals and extensions thereof anywhere in the world. Furthermore, you will identify such material (if any) in the work/contribution and provide full and appropriate acknowledgement of its source. If such permissions are not obtained in a timely manner, you will provide substitute material, revise the work/contribution accordingly and obtain the requisite substitute permissions, if necessary. If relevant, you will obtain medical patient releases from patients if information about them or illustrations of them are used in the work/contribution.

\section{COPYRIGHT TRANSFER}

Once the corresponding author has signed the Copyright Transfer form, Jaypee Brothers would accept no change in authorship or in the order of the authors listed in the work/contribution. Also by signing the concerned form, the author reassigns the rights of copublishing, or translation, including the digital rights, if considered necessary in future to the publisher. In the advent of occurrence any dispute, the matter would be resolved within the jurisdiction of New Delhi court.

\section{LEGAL OBLIGATIONS}

While all care has been taken to provide accurate and correct information in accordance with the date of publication, neither the authors, editors nor publisher takes any legal responsibility for any unintentional omission or error. The publisher makes no expressed or implied warranty with respect to the information contained herein. The published material cannot be photocopied for the following purposes: general distribution, promotion, new works or resale. If this is required, specific written permission requires to be obtained from the publisher. Exclusive rights to reproduce and distribute the articles in this journal have been protected by copyright. This also covers the rights to reproduce or distribute the article as well as the translation rights. No material published in this journal can be reproduced in digital format or stored in form of electronic databases, video disks, etc without the prior permission from the publisher.

\section{COPYRIGHT TRANSFER FORM}

I have read the above mentioned details related to copyright of the work/contribution submitted and I the author of

certifythat I willingly assignthecopyright of my work/contribution

to the publisher M/S Jaypee Brothers Medical Publishers (P) Ltd., who will have the exclusive right of producing (in print or digital format) the complete work or any portion of it.

I hereby certify that the work which I am submitting to the publisher is my own and does not contain any matter which in anyway is infringement of the copyright law.

Name:

Date signed:

\section{FINANCIAL DISCLOSURE}

This is to certify that I the author of

do not have any commercial association or financial interest in the publication of this work/contribution.

Name:

Date signed:

\section{CONFLICT OF INTEREST}

This is to certify that I the author of

do not have any commercial association or financial interest in the publication of this work/contribution.

Name:

Date signed: 